\title{
Plasma membrane-derived vesicles in sickle cell disease: a possible indicator of the continuous endothelial stimulation and/or injury to blood cells
}

\author{
Samuel Antwi-Baffour ${ }^{1,}$, , Abena Nyarkoah Wiredu², Ransford Kyeremeh ${ }^{1}$, \\ Seidu Abdulai Mahmood ${ }^{1}$ \\ ${ }^{1}$ Department of Medical Laboratory Sciences, School of Allied Health Sciences, College of Health Sciences, University of Ghana, P. O. \\ Box KB 143, Korle-Bu, Accra, Ghana \\ ${ }^{2}$ The Central Laboratory, Korle-bu Teaching Hospital, Accra, Ghana \\ Email address: \\ s.antwi-baffour@chs.edu.gh (S. Antwi-Baffour)
}

\section{To cite this article:}

Samuel Antwi-Baffour, Abena Nyarkoah Wiredu, Ransford Kyeremeh, Seidu Abdulai Mahmood. Plasma Membrane-Derived Vesicles in Sickle Cell Disease: A Possible Indicator of the Continuous Endothelial Stimulation and/or Injury to Blood Cells. American Journal of Biomedical and Life Sciences. Vol. 1, No. 4, 2013, pp. 99-102. doi: 10.11648/j.ajbls.20130104.14

\begin{abstract}
Plasma membrane-derived vesicles (PMVs) are released into circulation in response to normal and stress/pathogenic conditions. They are of tremendous significance for the prediction, diagnosis, and observation of the therapeutic success of many diseases. Knowledge of their functional properties would contribute to a better understanding of the pathological mechanisms leading to various diseases in which their levels are raised. The objective of this study was to quantify and compare the levels of PMVs in sickle cell disease patients (Hb SS and Hb SC) with non-sickle cell (Hb AA) subjects. The comparison will help us research and understand the processes that lead to their constitutive release in sickle cell disease patients than in their normal counterparts. A total of one hundred and fifty (150) sickle cell disease patients (study group) and blood donors (control group) that consented to partake in the study were recruited. There were 82 males and 68 females. Fifty (50) each of $\mathrm{Hb} \mathrm{SS}, \mathrm{Hb}$ SC and $\mathrm{Hb}$ AA samples were obtained. Sodium metabisulphite (sickling) test, Haemoglobin electrophoresis and quantification of PMVs were carried out on all the samples. The sickle cell disease patients had elevated levels; SS $\left(38.89 \pm 0.73 \times 10^{4} / \mathrm{ml} ; \mathrm{p}=0.01\right)$ and SC $\left(32.62 \pm 1.18 \times 10^{4} / \mathrm{ml} ; \mathrm{p}=0.01\right)$ as against the control subjects (Hb AA) who had average PMVs of $11.28 \pm 0.29 \times 10^{4} / \mathrm{ml} \mathrm{PFP} \mathrm{(mean} \pm \mathrm{SEM}$ ). It was concluded that both SS and SC (study) samples showed an increased count of PMVs as compared to the AA (control) samples, suggesting persistent endothelial stimulation and/or injury of blood cells leading to continuous shedding of PMVs in sickle cell disease patients.
\end{abstract}

Keywords: PMVs, Sickle Cell Disease, Electrophoresis, Flow Cytometer

\section{Introduction}

Sickle cell disease (SCD) is a group of related disorders where red blood cells have the tendency to deform (sickle) under low oxygen tension as in [1]. The complications of this disease are numerous and affect every organ and/or tissue in the body as in reference [1]. The disease is one of the most common inherited chronic haematological disorders worldwide that has no established cure to date, except in a few patients who have had successful bone marrow or stem cell transplantation as in $[1,2]$.

The homozygous state ( $\mathrm{Hb} \mathrm{SS}$ ) is the most common form of SCD, but interactions with other haemoglobin variants may give rise to others as seen in $\mathrm{Hb} \mathrm{AS}$ (the carrier/trait), $\mathrm{Hb} \mathrm{SC}, \mathrm{Hb} \mathrm{SD}, \mathrm{Hb} \mathrm{S} \beta+$ thalassaemia, and other genotypes as in [2, 3]. The molecular lesion of the sickle cell haemoglobin is a point mutation (GAG $\rightarrow$ GTG) in exon 1 of the $\beta$ globin gene resulting in the substitution of glutamic acid by valine at position 6 of the $\beta$ globin polypeptide chain as in [3]. This single-point mutation renders the sickle cell gene pleiotropic in nature with multiple phenotypic expressions associated with complex genetic interactions and modifiers that are not well understood as in $[3,4]$.

Plasma membrane-derived vesicles (PMVs) also referred to as microparticles (MPs), microvesicles or membrane 
vesicles (MVs) are sub membrane fragments. They are shed from the plasma membrane of cells during cell growth, activation, senescence, apoptosis and when stimulated as in [5]. PMVs therefore originate from cells which are surrounded by plasma membranes and many cell types release them as in reference [6]. The presence of basal levels of PMVs is common in healthy individuals and an increase in their release may be a hallmark of cellular alteration. Various publications have described the molecular and functional characteristics of PMVs suggesting the importance of PMVs as a key role player in various cellular processes rather than just inert bi-products of their activation as in [7].

In recent years, the interest for PMVs has increased substantially, not only because of their procoagulant properties, but also because of the role they are thought to play in inflammation processes and their ability to directly affect endothelial functions as in [8]. They are also indicated in a number of autoimmune diseases as well as malaria infestation whereby their number is known to increase as in reference [9]. SCD has pathophysiological similarities with inflammatory conditions in which the level of PMVs are increased and therefore it is suspected that, the level may be increased in SCD patients. If so, this will or can accelerate the immunological destruction of red blood cells in these patients, and this may in turn exacerbates their condition as in reference [10]. This work seeks to quantify/enumerate PMVs in SCD patients (SS and SC) and compare them with those of non-SCD patients. This, in an attempt towards understanding the process that lead to their release, the function and the role they may play in the haemolytic crisis of SCD.

\section{Materials and Methods}

This was a prospective case control study, conducted from the month of April to August, 2013.

\subsection{Study Population}

The study population was made up of one hundred and fifty (150) sickle cell disease patients (study group) who visited the sickle cell clinic at the Korle $\mathrm{Bu}$ teaching Hospital and blood donors (control group) of the Accra area blood centre. Out of the total number, 82 were males and 68 females. Their ages ranged from 5 to 40 years which were categorized into 5 - 10yrs; $11-20 \mathrm{yrs} ; 21-30 \mathrm{yrs}$ and 31 - 40yrs. Those with $\mathrm{Hb} \mathrm{SS}$ were $50, \mathrm{Hb} \mathrm{SC}$ also 50 and $\mathrm{Hb}$ AA 50 .

\subsection{Ethical Consideration}

Ethical clearance for this research was sought from the Ethics and Protocol Review Committee at the School of Allied Health Sciences, University of Ghana, Legon. All the participants gave their informed consent before their samples were collected.

\subsection{Materials}

Some of the materials needed for the work include: $2 \%$ sodium metabisulphite solution, glass slides, coverslips, Pasteur pipettes, slide rack, light microscope, electrophoresis buffer, electrophoresis tank and power pack, filter paper, blotting paper, cellulose acetate membranes, microplates, Annexin V reagent, phosphate buffered saline, centrifuge, flow cytometer, and water bath.

\subsection{Sample Collection and Processing}

$5 \mathrm{ml}$ of blood was collected from participants of the study into EDTA anticoagulant tubes, by venous puncture. Sickling test was carried out on the control group using the sodium metabisulphite method to confirm their sickling negative status or otherwise. $\mathrm{Hb}$ electrophoresis was also performed on the SCD patients to confirm their genotypes. The remaining samples were centrifuged at $1500 \mathrm{~g}$ for 3 minutes and the supernatant collected and transferred into plain sterile tubes and analysed for PMVs concentration.

For the sickling test, a drop of the freshly prepared sodium metabisulphite reagent was added to a drop of anticoagulated blood on a slide. A coverslip was applied to the slide and allowed to stand in a slide rack for 30 minutes. They were examined microscopically for the identification of the sickle cells. The same tests were performed on known $\mathrm{Hb} \mathrm{A}$ and $\mathrm{Hb} \mathrm{S}$ samples at the same time, to serve as controls.

In the electrophoresis testing, haemolysates were prepared from the samples. With the power supply disconnected, the electrophoresis tank was prepared by placing equal amounts of Tris-EDTA Borate buffer in each of the outer buffer compartments. Two chamber wicks in the buffer were made wet and one placed along each divider/bridge support, ensuring that they make good contact with the buffer. The cellulose acetate membrane was soaked by lowering it slowly into a reservoir and left for at least 5 minutes. The cellulose acetate strip was taken from the buffer and blotted between two layers of clean blotting paper. The applicator was cleaned and loaded by depressing the tips into the sample wells twice, and applying it first onto some clean blotting paper. It was then reloaded and the samples applied to the cellulose acetate membrane alongside controls. The cellulose acetate membranes were placed across the bridges. The power pack was connected and electrophoresis was carried out at 350 Volts for 25 minutes. Genotypes of the samples were identified and recorded.

With the flow cytometry analysis of PMVs, Frozen plasma was allowed to thaw and centrifuged at a higher speed (4000g, 60 minutes) to obtain platelet free plasma (PFP) and to remove any cell debris. The resultant supernatant was sonicated in a sonicating water-bath (Townson and Mercer Ltd, Croydon) for 5 times, 1 minute prior to further centrifugation, in order to disperse aggregated exosomes. The supernatant was then centrifuged at 25,000g for 90 minutes to pellet the PMVs. 
The supernatant was discarded, and the pellets containing the PMVs resuspended in $200 \mu$ l phosphate buffered saline. This was diluted in the ratio of 1:40 in Phosphate Buffered Saline (PBS), equal volume of annexin $\mathrm{V}$ was added and quantified using Guava Express plus (FACS- Flow Cytometer). All analysis were repeated three (3) times (technical repeats).

\subsection{Data Analysis}

Statistical analysis was carried out with the 16th students' edition of the Statistical Package for Social Sciences (SPSS version 20.0) for Microsoft Windows. Comparison among the three groups ( $\mathrm{Hb} \mathrm{SS}, \mathrm{Hb} \mathrm{SC}$ and $\mathrm{Hb}$ AA) was carried out using the Analysis of Variance (ANOVA) statistical model, after which the Turkey Posthoc analysis was also used for the pair-wise comparison of the test groups. A value of $\mathrm{p}<0.05$ was considered significant.

\section{Results}

The study population was made up of 82 males and 68 females who were between the ages of 5 to 40 years. Out of this number, 51 of the males had the sickling genotype and 31 were negative for the genotype. For the females, 49 had the genotype, whilst 19 were negative. The age category of 21 - 30yrs had the highest representation followed by the 31 - 40yrs (table 1).

Table 1. A table representing participants'age, sex and sickling status.

\begin{tabular}{llllllll}
\hline $\begin{array}{l}\text { Age } \\
\text { categories } \\
\text { (yrs) }\end{array}$ & SS & SC & AA & SS & SC & AA & $\begin{array}{l}\text { Percent } \\
\text { age } \\
(\%)\end{array}$ \\
\hline $5-10$ & 3 & 3 & 0 & 2 & 5 & 0 & 8.7 \\
$11-20$ & 6 & 5 & 6 & 5 & 7 & 3 & 21.3 \\
$21-30$ & 10 & 9 & 12 & 9 & 8 & 7 & 36.7 \\
$31-40$ & 8 & 7 & 13 & 7 & 6 & 9 & 33.3 \\
Total & 27 & 24 & 31 & 23 & 26 & 19 & 100 \\
\hline
\end{tabular}

The levels of PMVs obtained for each of the study group are expressed as PMVs number $\times 10^{4}$ per milliliter of platelet-free plasma and shown as mean \pm SEM. The blue bar represents data for $\mathrm{Hb} \mathrm{SS}$ patients, the red bar for $\mathrm{Hb}$ $\mathrm{SC}$ patients and the green bar for $\mathrm{Hb}$ AA subjects. Error bars represent SEM (fig. 1).

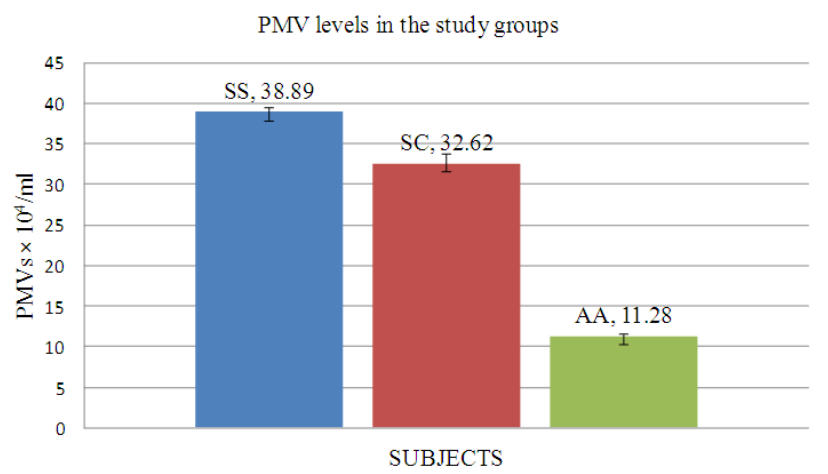

Fig 1. Total PMV s in each of the study group.
An ANOVA test was run to determine if there were statistically significant differences in levels of PMVs quantified in the different sickling statuses; $* \mathrm{p}<0.05$. The analysis showed that there is significant difference between the levels of PMVs in the different study groups (table 2).

Table 2. Statistical comparisons of group data among SCD patients ( $S S n=$ 50; $S C n=20)$ and non- $S C D$ subjects $(A A n=35)$.

\begin{tabular}{llllll}
\hline & $\begin{array}{l}\text { Sum of } \\
\text { Squares }\end{array}$ & df & $\begin{array}{l}\text { Mean } \\
\text { Squares }\end{array}$ & $\begin{array}{l}\text { F- } \\
\text { value }\end{array}$ & $\begin{array}{l}\text { P- } \\
\text { value }\end{array}$ \\
\hline $\begin{array}{l}\text { Between Groups } \\
\text { (SS, SC, AA) }\end{array}$ & 16123.09 & 2 & 8061.54 & 425.45 & $0.001^{*}$ \\
Within Groups & 1932.71 & 102 & 18.95 & & \\
Total & 18055.799 & 104 & & & \\
\hline
\end{tabular}

A post hoc test was performed to determine significant differences among paired groups. A value of $* \mathrm{p}<0.05$ was considered statistically significant (table 3 ).

Table 3. Pair-wise comparisons of group data among SCD patients and non-SCD subjects.

\begin{tabular}{|c|c|c|c|c|}
\hline $\begin{array}{l}\text { Subj } \\
\text { (I) }\end{array}$ & $(\mathrm{J})$ & $\begin{array}{l}\text { Mean Difference } \\
(\mathrm{I}-\mathrm{J})\end{array}$ & Std. Error & P-value \\
\hline AA & SS & $-27.61714^{*}$ & 0.95934 & $0.01 *$ \\
\hline AA & $\mathrm{SC}$ & $-21.34048^{*}$ & 1.22016 & $0.01 *$ \\
\hline SS & $\mathrm{SC}$ & $6.27667^{*}$ & 1.15168 & $0.01 *$ \\
\hline
\end{tabular}

\section{Discussion}

An increasing number of recent studies have analysed circulating PMVs in blood cells, platelets and endothelial cells in different vascular pathologies as seen in reference [11]. PMVs are of particular interest because of their possible diagnostic importance, as increased counts could signal endothelial cell injury. Thus, although circulating basal levels $\left(5-10 \times 10^{4}\right)$ of PMVs can be found in the blood of normal (healthy) individuals, increased numbers can be identified in individuals with certain diseases as in reference [12].

In this study, enumeration revealed significantly elevated PMVs levels for both groups of patients with sickle cell disease (SCD) as against those of non-SCD subjects (fig. 1). $\mathrm{Hb}$ SS patients recorded the highest levels, followed by the SC patients and the AA (control) subjects. The increased showed a genotype related pattern, with most severe form of the disease having higher amounts of PMVs than the less severe forms. The one way ANOVA analysis as well as the Post-hoc analysis showed statistically significant differences among the three study groups (table 2 and 3 ).

The findings of this study is in line with the findings of Allan et al in reference [12] which showed that sickle erythrocytes release vesicles as a result of repetitive sickling and unsickling during de-oxygenation (hypoxia) and re-oxygenation (a hallmark of the disease). This could therefore account for the higher PMVs levels in the SCD 
patients as compared to individuals in the healthy state. This implies that the level of PMVs in SCD patients can be used as a marker of the level of severity of erythrocyte stress and therefore crisis to assist in the management of the disease. There were some limitations during the research work, such as the sample size which could have been more than we obtained.

\section{Conclusion}

Both the SCD groups (SS and SC) showed an increased count of PMVs. This suggests continuous endothelial stimulation and/or injury to blood cells, consistent with the chronic vascular inflammatory process in the disease. Analysis of circulating PMVs populations therefore appears promising to provide useful information on the status of vascular endothelium in SCD patients. PMVs levels may be indicative of the character and severity of the vascular disease processes involved and could be of diagnostic use and value. Again, our findings may constitute valuable starting point to further research on mechanisms leading to the haemolytic crisis in SCD individuals.

\section{Acknowledgements}

We are grateful to the Central Laboratory, Administration and Laboratory of the Sickle Cell Clinic and the Accra Area Blood centre of the Korle-Bu Teaching Hospital for provision of samples for this work. Also the Building Stronger Universities for their financial assistance

\section{Abbreviations}

$\begin{array}{ll}\text { ANOVA } & \text { Analysis of Variance } \\ \text { EDTA } & \text { Ethylene diamine tetracetic acid } \\ \text { FACS } & \text { Fluorescence activated cell sorting } \\ \mathrm{Hb} & \text { Haemoglobin } \\ \text { PBS } & \text { Phosphate buffered saline } \\ \text { PFP } & \text { Platelet free plasma } \\ \text { PMVs } & \text { Plasma membrane-derived vesicles } \\ \text { RBC } & \text { Red blood cells } \\ \text { SCD } & \text { Sickle cell disease } \\ \text { SD } & \text { Standard deviation } \\ \text { SEM } & \text { Standard Error of Mean } \\ \text { SPSS } & \text { Statistical Package for Social Sciences } \\ \text { TEB } & \text { Tris - (hydroxymethyl aminomethane salt) } \\ & \text { EDTA Borate }\end{array}$

\section{References}

[1] Perumbeti A, Malik P (2010). Genetic correction of sickle cell anemia and $\beta$-thalassemia: progress and new perspective. The Scientific World Journal 10: 644-654.

[2] Kato GJ, Hebbel RP, Steinberg MH, Gladwin MT (2009). Vasculopathy in sickle cell disease: Biology, pathophysiology, genetics, translational medicine, and new research directions. Am J Haematol 84(9): 618-625.

[3] Lionnet F, Hammoudi N, KS Stojanovic1, AvellinoV, Grateau G, Girot R and Haymann JP (2012). Hemoglobin SC disease complications: a clinical study of 179 cases. Haematol 97(8): 1136-1141.

[4] Ballas SK, Lieff S, Benjamin LJ, Dampier CD, Heeney MM, Hoppe C, Johnson CS, Rogers ZR, Smith-Whitley K, Wang WC, Telen MJ (2010). Definitions of the phenotypic manifestations of sickle cell disease. Am J Haematol 85(1): 6-13.

[5] Morel O, Hugel B, Jesel L, Zobairi F, Bareiss P, Freyssinet JM, Toti F (2004). Procoagulant membranous microparticles and atherothrombotic complications in diabetics. Arch Mal Coeur Vaiss 97(10): 1006-1012.

[6] Boulanger CM, Scoazec A, Ebrahimian T, Henry P, Mathieu E, Tedgui A, Mallat Z (2001). Circulating microparticles from patients with myocardial infarction cause endothelial dysfunction. Circulation 104(22): 2649-52.

[7] Baj-Krzyworzeka M, Majka M, Pratico D, Ratajczak J, Vilaire G, Kijowski J, Reca R, Janowska-Wieczorek A, Ratajczak MZ (2002). Platelet-derived microparticles stimulate proliferation, survival, adhesion, and chemotaxis of hematopoietic cells. Exp Hematol 30(5): 450-459.

[8] Freyssinet JM, Toti F, Hugel B, Gidon-Jeangirard C, Kunzelmann C, Martínez MC, Meyer D (1999). Apoptosis in vascular disease. Thromb Haemost 82(2): 727-735.

[9] Tan KT, Tayebjee MH, Lynd C, Blann AD, Lip GY (2005).Platelet microparticles and soluble $P$ selectin in peripheral artery disease: relationship to extent of disease and platelet activation markers. Ann Med 37(1): 61-66.

[10] Shet AS, Aras O, Gupta K, Hass MJ, Rausch DJ, Saba N, Koopmeiners L, Key NS, Hebbel RP (2003). Sickle blood contains tissue factor-positive microparticles derived from endothelial cells and monocytes. Blood 102 (7): 2678-2683.

[11] Combes V, Coltel N, Alibert M, Van Eck M, Raymond C, Juhan-Vague I, Grau GE, Chimini G (2005). ABCA1 gene deletion protects against cerebral malaria: potential pathogenic role of microparticles in neuropathology. Am J Pathol 166(1): 295-302.

[12] Allan D, Limbrick AR, Thomas P, Westerman MP (1981). Microvesicles from sickle erythrocytes and their relation to irreversible sickling. Br J Haematol 47: 383-390

[13] Doeuvre L, Plawinski L, Toti F, Anglés-Cano E (2009). Cell-derived microparticles: a new challenge in neuroscience. Journal of Neurochemistry 110(2): 457-468. 